\title{
The Autophagic Response to Exercise Training of the Skeletal Muscle Fibers in Young and Old Mice
}

\author{
Yong An $\mathrm{Kim}^{1}$ and Young Sang $\mathrm{Kim}^{2} \star$ \\ ${ }^{1}$ Intitute of Biotechnology, Chungnam Nat'l Univertisy, Daejon 305-764, korea \\ ${ }^{2}$ Department of Biochemistry, College of Natural Sciences, Chungnam Nat'1 University, Daejon 305-764, korea
}

Received November 20, 2010/Accepted February 28, 2011

\begin{abstract}
Autophagy, a highly conserved mechanism of internal quality control, is essential for the maintenance of cellular homeostasis and for the orchestration of an efficient cellular response to stress. During aging, the efficiency of autophagic degradation declines and intracellular waste products accumulate. Therefore, the aim of this study is to investigate the effects of exercise on autophagic response in skeletal muscle. Twenty-four Young (4 month) and Old (12 month) ICR-type white male mice were divided into a control group (CON: $\mathrm{n}=6$ ) and exercise training group (Tr: $\mathrm{n}=6)$ after an adaptation period of 1 week. Exercise consisted of treadmill running at $16.4 \mathrm{~m} / \mathrm{min}$ with a $4 \%$ incline, $40 \mathrm{~min} /$ day and 5 days/week for 8 weeks. Cervical dislocation was performed at 48 hours after the last round of exercise, after which the gastrocnemius skeletal muscle were immediately collected. The results of verifying autophagy formation showed that the Sarcopenia index was decreased in the Old mice compared to the Young. However, it increased with exercise training in the Old. Lipidation LC3- П, Becline -1 , and Atg7 were decreased in the Old mice compared to the Young. However, Lipidation LC3- II was significantly increased in the trained Old mice (Young:1 Vs Old:1.32 $\pm 0.042, p<0.05$ ). Based on these data, we suggest that autophagy regulatory events are the attenuated in Old mice, but that they are enhanced with exercise training.
\end{abstract}

Key words : Aging, Skeletal muscle, Exercise Training, Autophagy

\section{서 론}

골격근은 인체가 움직임을 가능하게 하는 행위자이다. 근섬 유의 세포질은 반복적으로 이루어진 수축단백질로 채워져 있 으며, 그 구조는 기계적 장력을 생성하고 지속하도록 구조화 되어있다[17]. 그러므로 인체의 약 $40 \%$ 를 차지하는 근육의 단 백질 합성과 분해의 균형은 중요하다. 안정한 유사분열후 조 직(Postmitotic tissues)의 크기는 단백질전환(protein turnover)에 의해 조절되고 대부분의 진핵세포내에 존재하는 단백 질들은 두가지 단백질 분해시스템[proteolytic system(ubiquitin-proteasome과 autophagy-lysosome)]을 경유하여 감성 (degradation)된다. 심장근과 골격근에서 단백질 분해시스템 (proteolytic system)은 단백질과 소기관의 정상적인 구성요소 를 보존하기 위해 정교하게 조절되어진다[8]. 그러나, 노후된 세포와 조직은 약화된 Autophagy 의해 protein turnover 작용 이 장애를 입게되어 손상, misfold, ubiquitinate가 작용하여 응집된 단백질이 축적되고 결국 항상성과 생존 유지에 요구되 는 다양한 생물학적 기작의 효율성을 저하시켜 수명 단축과 노화의 원인이 된다[3,9,14-16,20].

또한, autophagy 유지는 골격근의 항상성을 위해 중요하다.

*Corresponding author

Tel : +82-42-821-7523, Fax : +82-42-822-7548

E-mail : young@cnu.ac.kr
골격근에서는 간, 췌장과 같은 다른 주요 대사조직과 비교하 여 특이적이다. 금식 동안 대부분 조직의 autophagy 활성은 마지막 몇 시간에서 일시적으로 나타나지만 골격근은 매일 지속적으로 autophagosome의 발생이 끓임없이 나타난다 [12,17]. 그러나, 골격근에 특이적으로 작용하는 skeletal muscle specific autophagy knockout mice에서 muscle dysfunction과 myopathy의 특징이 나타나는 것으로 밝혀졌다. $\operatorname{Atg} 7^{-/-}$mice는 출생 후 약 40일 후에 야생형(Wild Type)과 비교하여 체중, 근량/체중, 힘의 생성 그리고 근섬유의 횡단면 이 감소하는 것으로 나타났다. 또 다른 변화는 $z$-line의 정렬불 량, 팽창된 미토콘드리아와 근형질세망 그리고 비정상적인 수축막 구조는 Atg7-deficient livers와 Atg5-deficient heart에 서 모두 유사하게 관찰되어, autophagy의 억제/변화는 근섬 유 변성과 약화에 원인이 되고 근량 유지를 저해하는 주요 기작이 될 수 있다고 제안하였다[8,18]. 따라서, 노후된 개체의 골격근에서 약화된 autophagy 기능의 개선을 통해 손상된 세 포소기관 및 변형된 단백질의 축적을 정상적으로 제거하기 위한 방법이 요구된다. 이를 위해 노후된 개체에게 $8 \%$ 식이제 한과 자율적인 휠운동과 식이제한을 동시에 적용한 후 $\mathrm{au}^{-}$ tophagy의 변화를 보고하였다[19]. 그러나 이러한 결과는 에 너지부족 및 결핍에 노출된 조건이며 순수한 운동 중재효과는 아니므로 정상적인 조건에서 정확한 운동 중재효과의 연구가 필요하다. 또한, 노화에 의한 autophagy 관련연구는 균(yeast), 
꼬마선충(c.elegans), 초파리(drosophila) 등의 대상에 국한되 어있고 척추동물에서의 연구는 부족한 실정이다. 그러므로, 본 연구의 목적은 골격근에서 연령과 운동훈련에 따른 $\mathrm{au}^{-}$ tophagy 관련 단백질 변화를 규명하는데 있다.

\section{재료 및 방법}

\section{실험 대상}

실험동물은 생후 Young (4개월)과 Old (12개월) 된 ICR계 수컷을 이용하여, 일주일의 적응기간을 거친 후 무작위로 각 각 운동집단 $(\mathrm{Tr} ; \mathrm{n}=6)$, 통제집단 $(\mathrm{Con} ; \mathrm{n}=6)$ 로 설정하였다. 사 료와 물은 자유스럽게 섭취하도록 하였다. 온도 $\left(22 \pm 1^{\circ} \mathrm{C}\right)$, 습도 $(55 \pm 3 \%)$, 밤낮은 자연주기 조건에서 사육하였다.

\section{운동 방법}

운동그룹은 트레드밀 속도 $10 \mathrm{~m} / \mathrm{min}$, 경사도 $0 \%, 10$ 분 2일 간의 적응기를 실시하였으며 8 주간 주당 5 회 운동을 실시하 였다. 8주간의 본 운동을 위한 트레드밀 프로토콜은 트레드밀 경사도 $4 \%$, 속도 $16.4 \mathrm{~m} / \mathrm{min}$ 로 40 분간 지속하였고[5], 운동기 간 동안 동일한 시간대에 운동을 수행하였다.

\section{조직적출 및 분석}

마지막 운동 종료 48시간 이후에 비복근을 적출한 후, 액화 질소에 급속 냉동시켜 분석 시까지 $-70^{\circ} \mathrm{C}$ 에서 보관하였다. 통 제 집단 동물들도 같은 시간에 동일한 방법으로 조직을 적출 하고 보관하였다.

\section{Western Blotting}

각 조직에서 cell lysis buffer를 이용하여 $2 \mathrm{ug} / \mathrm{lul}$ 단백질 을 얻었다. 단백질 분리하기 위해 $10 \%$ polyacrylamide one-Gel (Elpis Biotech, Korea)을 사용하여 SDS-PAGE를 시행 한 후 PVDF membrane (polyvinylidine difluoride)로 gel transfer 하였다. Membrane을 TBS-T로 1회 세척한 후 $3 \%$ bovine serum albumin/TBS-T로 2시간 이상 blocking한 후, TBS-T로 1 회 세척하였다. 일차 항체는 tubulin antibody (1:5,000 dilution), LC3 antibody (1:1,000 dilution), Becline-1 antibody (1:1,000 dilution), 그리고 Atg7 antibody (1:1,000 dilution)을 각각 첨가 후 membrane과 $4^{\circ} \mathrm{C}$ 에서 overnight 반응 시킨 후 TBS-T 용액으로 5분씩 6회 세척하였다. 이차 항체로는 horseradish peroxidase (HRP) 결합된 anti-mouse IgG antibody (1:15,000 dilution) 또는 anti-rabbit $\operatorname{IgG}$ antibody (1:20,000 dilution)를 membrane과 $4^{\circ} \mathrm{C}$ 에서 1 시간 반응시킨 후 TBS-T 용액으로 5 분씩 6회 세척하였다. 반응 후, $\mathrm{HRP}$ 의 기질 인 ECL용액으로 발색반응을 일으켜 X-ray film에 감광하여 분석하였다.

\section{자료 처리}

본 실험의 자료는 SPSS 13.0 통계프로그램을 이용하여, T-test를 실시하였다. 유의수준은 $p<0.05$ 로 하였다.

\section{결 과}

이 연구는 연령에 따른 8주간의 트레드밀 운동 효과를 알아 보기 위하여 비복근내에서 autopahgy 관련 단백질의 변화를 검사한 후, 다음과 같은 결과를 얻었다.
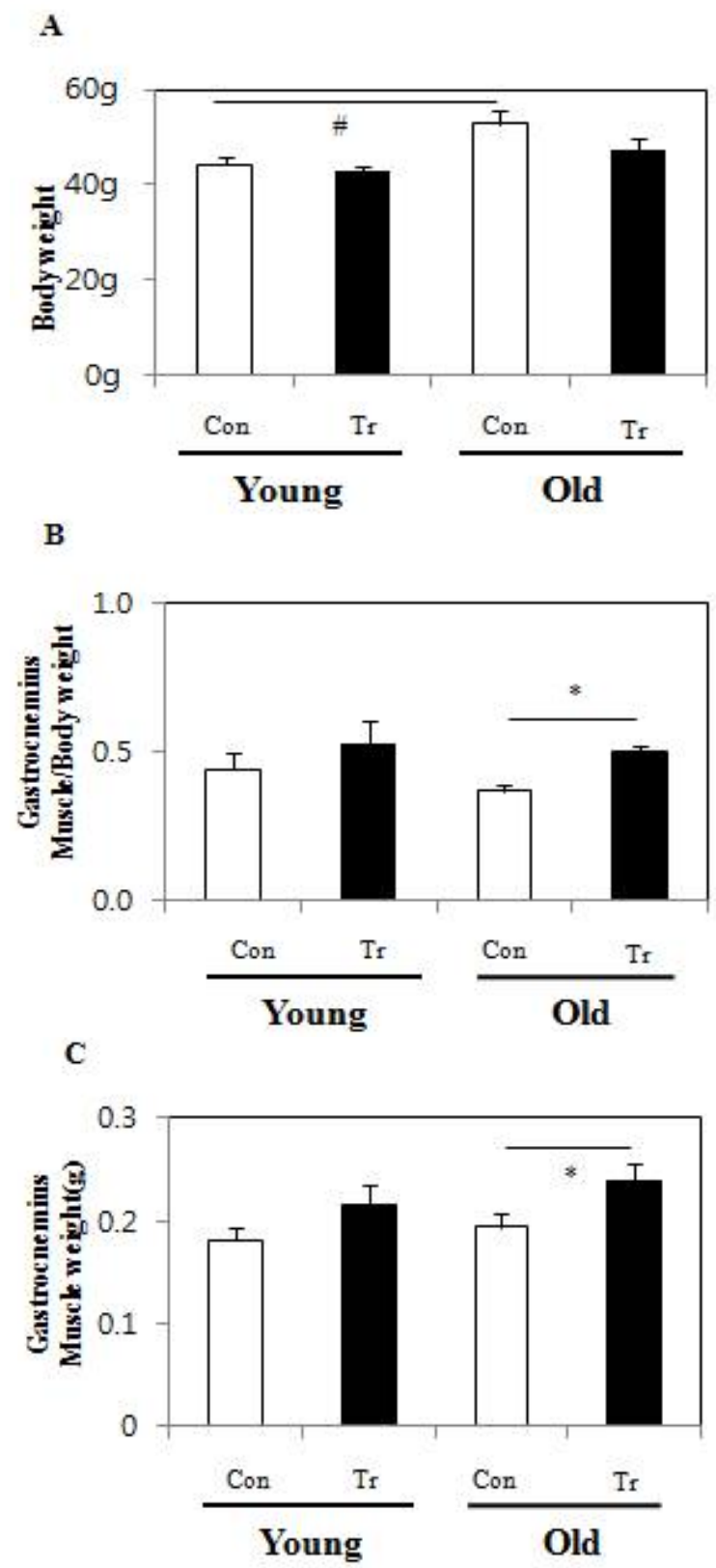

Fig. 1. Body weight (BW;g), gastrocnemius weight (g) and relative weight ( $\mathrm{g} \mathrm{BW}$ ) in young, old and exercised ICR mice. Data presented as mean \pm SEM; same indices represent significant difference at $p<0.05$. 


\section{Weight}

운동 전 전체 체중은 Young $(44.103 \pm 1.81 \mathrm{~g})$ 그룹과 비교하 여 Old $(52.904 \pm 2.71 \mathrm{~g})$ 그룹이 유의하게 높았고 $(p<0.05)$, 근량 /체중 비율은 Young 그룹과 비교하여 Old 그룹이 낮았으나 통계적 유의성은 없었다(Fig. 1A, 1B). 운동 훈련에 의한 전체 체중은 Young (Con; 44.103 $\pm 1.81 \mathrm{Vs} \mathrm{Tr} ; 43.035 \pm 0.79 \mathrm{~g}$ ) 그룹에 서 차이가 없었고 Old (Con; $52.904 \pm 1.37 \mathrm{Vs}$ Tr; $47.484 \pm 1.44$ $\mathrm{g}$ ) 그룹에서 감소하는 경향이 나타났다(Fig. $1 \mathrm{~A}$ ). 그러나 운동 훈련에 의한 근량/체중 비율은 Young 그룹에서 증가하는 경 향은 나타났으나 유의성은 없었다. 반면 Old (Con; $0.367 \pm 0.02$ Vs Tr; 0.502 \pm 0.06 ) 그룹에서는 유의하게 증가하였고(Fig. 1B), 근육량 또한 Old (Con; $0.194 \pm 0.013 \mathrm{Vs} \mathrm{Tr} ; 0.238 \pm 0.017 \mathrm{~g}$ ) 그룹 에서 유의하게 증가하는 것으로 나타났다( $p<0.05$ ) (Fig. 1C).

\section{LC3}

Microtubule-associated protein 1b-Light Chain3 (LC3)는 $-17 \mathrm{kDa}$ 의 molecular mass를 갖는 soluble protein으로 mammalian tissues와 cultured cells에서 흔하게 분포하고 있다. LC3I의 cytosolic form은 phosphatidylethanolamine $(\mathrm{PE})$ 과 결합하여 LC3-phosphatidylethanolamine conjugated (LC3 II) 형태로 전환된다. 이것은 autophagosomal membranes 형 성을 위해 중요한 단계이다. LC3는 는 -terminus 인접부위에 lipidation과 site specific proteolysis에 의해 만들어진다. 그러 므로, Autophagic activation의 특징은 LC3프를 포함한 cellular autophagosome의 형성이다.

Old는 Young 그룹과 비교하여 유의하게 낮아져 있으며 $(p<0.05), 8$ 주간 트레드밀 운동은 Young 그룹에서 변화가 나타 나지 않았다. 그러나 Old 그룹에서 대조군과 비교하여 운동훈 련집단이 유의하게 증가하였다( $p<0.05)$ (Fig. 2).

\section{Beclin-1}

Beclin-1은 autophagy related gene (Atg6)으로 classIII phosphoinositide 3-kinase complex (PI3KC3)와 결합하여 초 기 autophagosome 형성을 유도하는데 주요 구성단백질이다.

Old는 Young 그룹에 비해 유의하게 낮아져 있으며 ( $p<0.05), 8$ 주간 트레드밀 운동은 Young 그룹에서 대조군과 비교하여 유의하게 감소하였다. 그러나 Old 그룹에서 대조군 과 비교하여 운동훈련집단이 증가하는 경향은 있으나 유의성 은 나타나지 않았다(Fig. 3).

\section{Atg7}

Atg7은 ubiquitin-E1-like enzyme homolog이며, Atg8과 $\mathrm{PE}$ (phosphatidylethanolamine) 그리고 Atg12와 Atg5의 결합 을 요구한다

Old는 Young 그룹과 비교하여 유의하게 낮았다 $(p<0.05)$. 그러나 8주간 트레드밀 운동은 Young 과 Old 모두에서 변화가 나타나지 않았다(Fig. 4).

\section{고 찰}

Autophagy 기능은 모든 진핵세포에서 나타나며, 균(yeast) 에서 인간에게 이르기까지 잘 보존되어 왔고, 리소좀 경로를 경유하여 세포질 구성요소들과 세포소기관들의 degradation 을 조절한다[10,11].

Autophagy는 amino acid starvation, unfolded protein response 또는 바이러스 감염과 같은 스트레스 조건에서 활성화 된다[13]. lysosomal lumen은 세포질 구성요소들의 운송수단 에 의존적이며 1) macroautophagy, 2) microautophagy, 3) chaperone-mediated autophagy로 나뉘어진다. 일반적으로 autopahgy는 macroautophagy를 일컫는데, 분해된 cytoplasm 일부분을 autophagosome으로 포장한 후, 감성을 위해 lysosomal vesicles과 융합을 이룬다.

Autophagy 시작은 분리막(isolation membrane)이라 불 리는 phagophore에 의해 세포질 구성요소(cytosol and/or
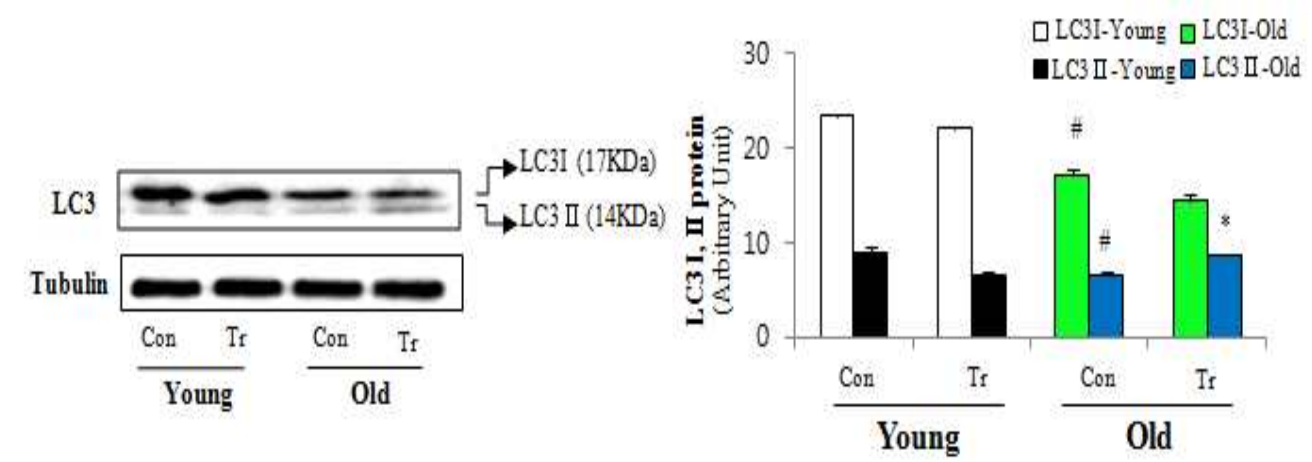

Fig. 2. Protein expression of LC3 in tissue extracts of Gastrocnemius muscle from young (4 month), old (12 month) and exercised mice. LC3 protein expression was determined by Western blot analysis. The inset shows representative blot for LC3. The data are presented as means \pm SE. CON, sedentary control; Ex, Exercise Training. ${ }^{*}$ Significantly different from CON $(p<0.05)$. "Significantly different from Young $(p<0.05)$. 

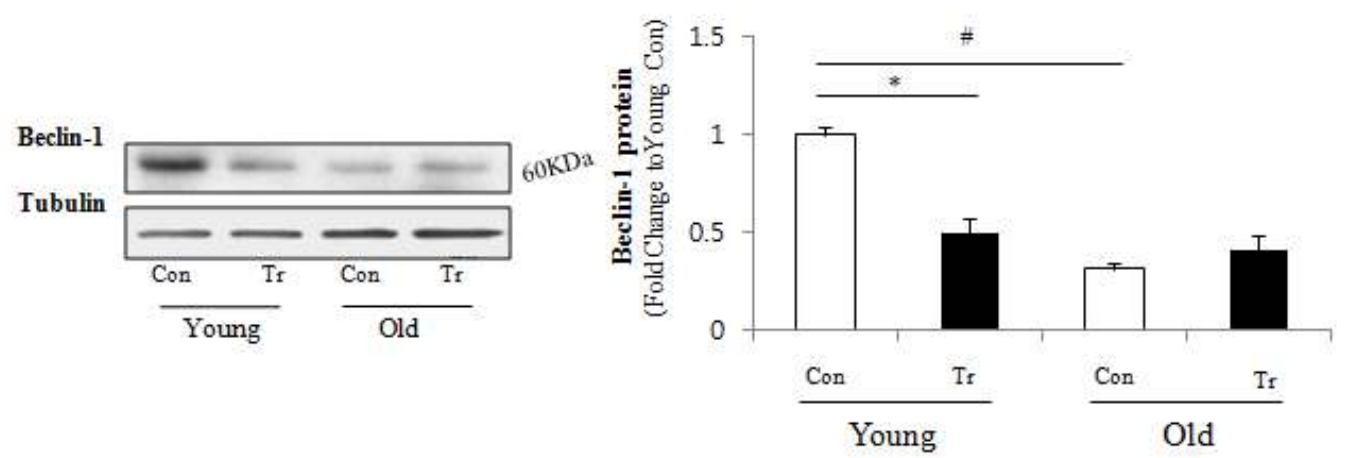

Fig. 3. Protein expression of Beclin-1 in tissue extracts of Gastrocnemius muscle from young (4 month), old (12 month) and exercised mice. Beclin-1 protein expression was determined by Western blot analysis. The inset shows representative blot for Beclin-1. The data are presented as means \pm SE. CON, sedentary control; Ex, Exercise Training. ${ }^{*}$ Significantly different from CON $(p<0.05)$. " Significantly different from Young $(p<0.05)$.

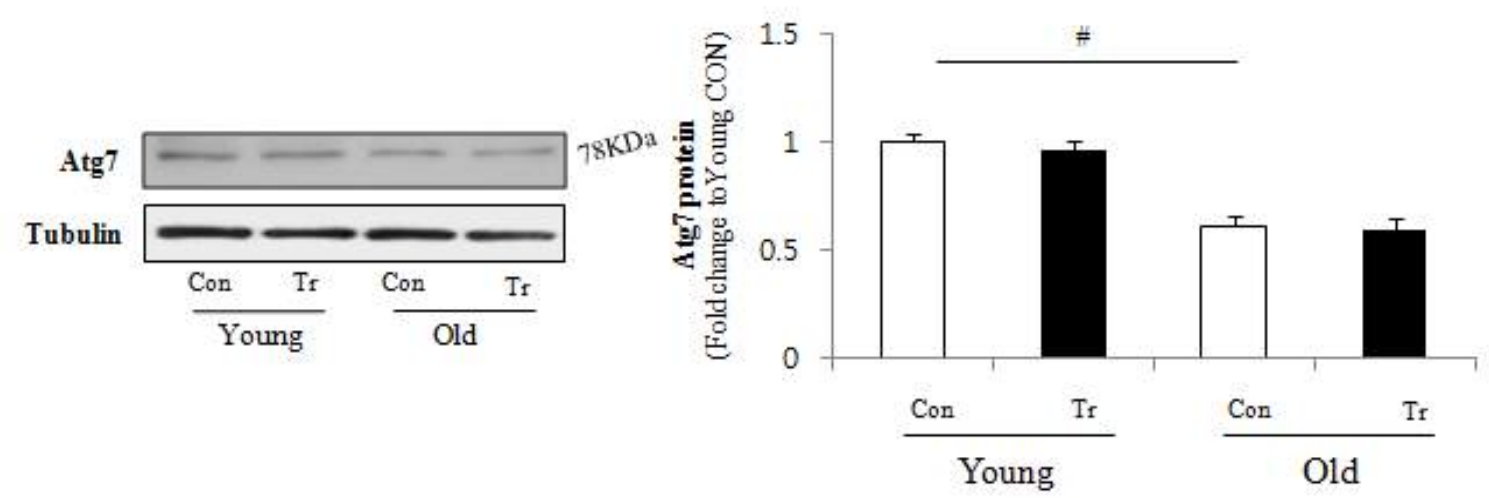

Fig. 4. Protein expression of Atg7 in tissue extracts of Gastrocnemius muscle from young (4 month), old (12 month) and exercised mice. Atg7 protein expression was determined by Western blot analysis. The inset shows representative blot for Atg7. The data are presented as means \pm SE. CON, sedentary control; Ex, Exercise Training. ${ }^{*}$ Significantly different from CON $(p<0.05)$. ${ }^{\#}$ Significantly different from Young $(p<0.05)$.

organelles)를 순차적으로 둘러싼다. 이때 Double-membraned vesicles안에 격리된 기질 형태를 autophagosomes 으로 불린다.

Autophagosome 형성을 위해서는Atg1과 $\operatorname{Atg} 13$ 의 상호작 용이 있어야 한다. Atg1의 포유류 동류(mammalian homolog) 는 ULK1이라고 불리며, serine-threonine kinase이다. autophagy 활성화 신호기작에 기능을 가지고 있다. mTOR가 억제될 때, Autopahgy가 유도되는 동안 Atg13이 탈인산화 되며 Atg1-Atg13 complex의 합성이 증가한다. 반대로 mTOR가 활 성화될 때 Atg13의 인산화는 Atg1-Atg13complex로부터 $\operatorname{Atg} 13$ 의 분리를 유도 하여 Atg1 kinase activity가 약하게 된 다. 그 결과 autopahgy가 억제된다. 그러므로 autopahgy는 mTOR signal의 반대기작에 해당된다.

Atg6 기능은 autophagosomes 형성 초기에 관여한다. Atg6 의 mammalian homolog는 Beclin 1 으로 불린다. 이 단백질은 autophagy 조절의 중심역할을 한다. Beclin 1은 class III phos- phatidylinositol 3-kinase (PI3-kinase) Vps34와 같이 complex 를 이룬다.

Autopahgosome 형성 후 소낭 신장(vesicle elongation) 단 계는 두 가지 ubiquitin-like conjugation system에 의해 이루 어진다. 첫 번째 경로는, E1-like enzyme Atg7과 E2-like enzyme $\operatorname{Atg} 10$ 의 도움으로 $\operatorname{Atg} 12$ 와 Atg5의 covalent conjugation을 포함한다. 두 번째 경로는, protease Atg4, E1-like enzyme Atg7 그리고 E2-like enzyme Atg3의 순차적인 작용 에 의해 LC3는 phosphatidylethanolamine $(\mathrm{PE})$ 과 결합한다. LC3의 C-terminal glycine 120에서 분할이 일어나고 노출된 glycine 부분에 PE가 공유결합을 이루어 LC3- П를 형성한다 [4,7,10]. PE는 막에서 발견되는 cephalin 지질형태로 소수성이 기 때문에 SDS-page gel에서 분자무게가 많이 나감에도 불구 하고 LC3-I 보다 빠르게 이동한다. 이러한 특징 때문에 LC3-II 의 양은 autophagosome의 수와 연관되어 있으며 autopahgy 표지자로 사용된다[1,2]. 
최종적으로 Autophagosome은 lysosome과 결합하여 $\mathrm{au}^{-}$ tolysosome을 만들어 손상된 단백질과 세포소기관을 가수분 해한다.

이러한 autophagy의 생리적 기능은 서두에 언급된 바와 같 이 영양소결핍조건에서 amino acid 유지를 위해 작용한다 [13]. 그러나 정상조건에서 autophagy는 지속적인 protein turnover를 통해 세포내 질적 조절을 위해 중요하다. Atg5와 Atg7과 같은 autophagy 결손 직후 비정상적인 ubiquitinated protein과 세포소기관들 이 간[18], 신경계[6], 근육[8] 에서 축적된다. 더욱이, $\operatorname{Atg} 5^{-/-}$mice에서 일차 마우스 배아 섬유아 세포(primary mouse embryonic fibroblasts)는 단백질 응집 (protein aggregates)이 초기단계에 나타나지 않았으나 노쇠단 계후반(later senescent phases)에서 일어난 것은, 질적인 조절 은 빠르게 분열되는 세포(dividing cells)보다 비분열 (nondividing), 휴지세포(quiescent cells)에서 더욱 중요하다 고 제안하였다[11].

이러한 세포 내 질적조절과 항상성 유지에 주요한 역할을 담당하는 autopahgy는 노후된 개체에서 그 기능이 약해진다 [3,9,14-16,18-20]. 약화된 autophagy 기능의 개선을 위해 24개 월 된 344 fischer rats을 대상으로 $8 \%$ 식이제한 그룹 그리고 자발적인 휠 운동과 식이제한을 동시에 적용한 그룹으로 나누 어 실험한 결과[19] plantaris에서 LC3표 와 beclin-1단백질 변 화는 6개월 된 그룹과 비교하여 24개월 된 그룹이 유의하게 높게 나타났다. 그러나 식이제한그룹과 복합처치그룹에서 유 의한 변화는 나타나지 않았고 오히려 감소하는 경향이 나타났 다. 또한 atg7 단백질은 6개월 된 그룹과 24개월 된 그룹간 차이가 나타나지 않았으나 식이제한그룹과 복합처치그룹에 서 24개월 된 그룹과 비교하여 유의하게 증가하는 것을 보고 하여 autopahgy 관련 단백질이 일관된 경향이 나타나지 않았 다. 이는 에너지 부족 및 고갈과 같은 불균형 조건에서 $\mathrm{au}^{-}$ tophagy가 증가하기 때문에 자율적인 휠 운동과 $8 \%$ 식이제한 의 병행은 추가적인 에너지 요구가 발생하므로 정상조건에서 의 결과와 다를 것으로 판단된다. 즉, 정상적인 영양조건에서 운동 효과의 결과가 autophagy 관련 단백질의 변화를 정확하 게 해석할 수 있는 실험조건이 된다. 그러므로 본 실험의 결과 는 노후된 개체에서 autophagy 관련 단백질 변화가 증가한 것은 순수한 운동효과라고 할 수 있다.

Mcmullen 등[9]은 6-, 18-, 그리고 30-개월 된 344-Brown Norway F1 hybrid rats의 안외근(extraocular muscle, EOM) 을 대상으로 실험한 결과, 6 개월 된 개체와 비교하여 30 개월된 개체에서 $\operatorname{Atg} 5, \operatorname{Atg} 7, \mathrm{LC} 3$ 가 모두 유의하게 감소하였다. 그러 므로, autopahgy 관련 단백질의 감소는 비정상적이고 손상된 단백질의 축적을 유도하여 protein turnover의 효율성을 감소 시켜 세포의 기능에 영향을 미칠 것으로 제안하였다. 또한, 30 개월과 비교하여 오히려 18개월에서 Atg7이 약2배 감소하 였음에도 불구하고, LC3- 느는 약 1.7 배 증가하여 autopahgy
관련 단백질 간에 변화 비율에 차이를 보고하였고, 그 이유는 18 개월 된 개체의 안외근에서는 노화가 빠르게 이행되는 연령 (transitional age) 상태로서 LC3 감소를 위한 보상작용이 시도 된 것으로 해석하였다.

본 실험에서도 Young 그룹과 비교하여 Old 그룹의 비복근 에서 LC3- II의 감소와 autophagosome 형성 초기에 관여하는 beclin-1과 LC3- I의 lipidation에 관여하는 Atg7이 낮게 나타 났다. 따라서, 노화로 인해 잠재적으로 degradation과 protein turnover 기능의 약화로 인한 근세포기능 저하를 초래할 수 있을 것이다. 그러나, Old그룹에서 8주간의 트레드밀 운동은 LC3- 기 가 유의하게 증가하여 degradation과 protein turnover 기능이 개선되었을 것으로 사료된다. 그러나, beclin-1과 Atg7 는 증가하는 경향은 있으나 통계적 유의성은 나타나지 않았 다. 이러한 결과는 앞서 언급된 안외근을 이용한 실험[9]과 마 찬가지로 autophagy 관련 단백질 간에 변화 비율과 외부 자극 에 의한 민감성 또는 역치의 차이가 있을 것으로 사료된다. 또한, 운동자극의 반응에 의한 beclin-1과 Atg7는 autophagosome 형성의 발달과정 단계에 의한 시간적 차이 그리고 LC3II 형성을 위한 효율성에 의한 차이가 있을 것으로 사료된다. 반면에, 8주간 트레이닝에 의한 autophagy 관련 단백질은 연령에 따라 다르게 반응하는 것으로 보여진다. Young 그룹에 서 운동훈련에 의해 LC3- I와 Atg7은 감소하는 경향이 나타 났고 beclin-1은 유의하게 감소하였다. 이는 노후된 개체와 비 교하여 젊은 개체의 근육단백질은 풍부하고 운동으로 인한 근량의 증가로 인해 degradation과 protein turnover의 저하 가 아닌 autophagy의 항상성 범주 내에서 효율성 개선일 것으 로 추측된다.

그러므로 규칙적인 운동에 의한 autophagy 관련 단백질의 변화는 연령에 따라 다르게 변화하는 것을 알 수 있었고 노후 된 개체에서 근량의 증가와 더불어 약화된 autophagy 관련 단백질이 증가하는 것을 알 수 있었다. 이러한 결과는 손상된 세포소기관 및 변형된 단백질의 제거 기능이 개선 되었을 것 으로 사료된다. 그러나 autophagy 증가로 인한 degradation과 protein turnover 기능 개선에 직접적인 영향을 규명하지 못한 한계점이 있기에 degradation의 대상이 되는 dysfunctional mitochondria 등의 변화에 관한 추가적인 연구가 이루어져야 한다.

\section{감사의 글}

이 논문은 2010년도 정부(교육과학기술부)의 재원으로 한 국연구재단의 지원을 받아 수행된 기초연구사업임(No. 20100015964).

\section{References}

1. Barth, S., D. Glick, and K. F. Macleod. 2010. Autophagy: 
assays and artifacts. J. Pathol. 221, 117-124.

2. Chen, Y., M. B. Azad, and S. B. Gibson. 2010. Methods for detecting autophagy and determining autophagy-induced cell death. Can. J. Physiol. Pharmacol. 88, 285-295.

3. Cuervo, A. M. 2008. Autophagy and aging: keeping that old broom working. Trends Genet. 24, 604-612.

4. Eskelinen, E. L. and P. Saftig. 2009. Autophagy: a lysosomal degradation pathway with a central role in health and disease. Biochim. Biophys. Acta 1793, 664-673.

5. Kim, K. B., Y. A. Kim, and J. J. Park. 2010. Effects of 8 week exercise on bcl-2, bax, caspase- 8 , caspase -3 and HSP70 in mouse gastrocnemius muscle. J. Life Sci. 20, 1409-1414.

6. Komatsu, M., S. Waguri, T. Chiba, S. Murata, J. Iwata, I. Tanida, T. Ueno, M. Koike, Y. Uchiyama, E. Kominami, and K. Tanaka. 2006. Loss of autophagy in the central nervous system causes neurodegeneration in mice. Nature 441, 880-884.

7. Maiuri, M. C., E. Zalckvar, A. Kimchi, and G. Kroemer. 2007. Self-eating and self-killing: crosstalk between autophagy and apoptosis. Nat. Rev. Mol. Cell Biol. 8, 741-752.

8. Masiero, E., L. Agatea, C. Mammucari, B. Blaauw, E. Loro, M. Komatsu, D. Metzger, C. Reggiani, and S. Schiaffino, and M. Sandri. 2009. Autophagy is required to maintain muscle mass. Cell Metab. 10, 507-515.

9. McMullen, C. A., A. L. Ferry, J. L. Gamboa, F. H. Andrade, and E. E. Dupont-Versteegden. 2009. Age-related changes of cell death pathways in rat extraocular muscle. Exp. Gerontol. 44, 420-425.

10. Mizushima, N. 2007. Autophagy: process and function. Genes Dev. 21, 2861-2873.

11. Mizushima, N. 2009. Physiological functions of autophagy.
Curr. Top Microbiol. Immunol. 335, 71-84.

12. Mizushima, N., A. Yamamoto, M. Matsui, T. Yoshimori, and Y. Ohsumi. 2004. In vivo analysis of autophagy in response to nutrient starvation using transgenic mice expressing a fluorescent autophagosome marker. Mol. Biol. Cell 15, 1101-1111.

13. Mortimore, G. E., N. J. Hutson, and C. A. Surmacz. 1983. Quantitative correlation between proteolysis and macroand microautophagy in mouse hepatocytes during starvation and refeeding. Proc. Natl. Acad. Sci. USA 80, 2179-2183

14. Rajawat, Y. S., Z. Hilioti, and I. Bossis. 2009. Aging: central role for autophagy and the lysosomal degradative system. Ageing Res. Rev. 8,199-213.

15. Salminen, A. and K. Kaarniranta. 2009. Regulation of the aging process by autophagy. Trends Mol. Med. 15, 217-224

16. Salminen, A. and K. Kaarniranta. 2009. SIRT1: regulation of longevity via autophagy. Cell Signal. 21, 1356-1360.

17. Sandri, M. 2009. Autophagy in skeletal muscle. FEBS Lett. $584,1411-1416$

18. Wohlgemuth, S. E., D. Julian, D. E Akin, J. Fried, K. Toscano, C. Leeuwenburgh, and W. A. Dunn. 2007. Autophagy in the heart and liver during normal aging and calorie restriction. Rejuvenation Res. 10, 281-292.

19. Wohlgemuth, S. E, A. Y. Seo, E. Marzetti, H. A. Lees, and C. Leeuwenburgh. 2010. Skeletal muscle autophagy and apoptosis during aging: effects of calorie restriction and life-long exercise. Exp. Gerontol. 45, 138-148.

20. Yen, W. L. and D. J. Klionsky. 2008. How to live long and prosper: autophagy, mitochondria, and aging. Physiology 23, 248-262.

\section{초록 : 노화에 따른 골격근에서 운동훈련에 의한 자식작용 반응}

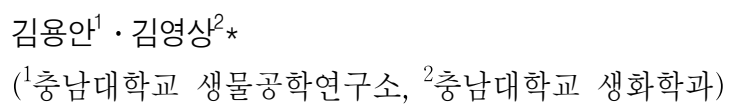

Autophagy는 항상성 유지와 스트레스반응을 효율적으로 조정하기 위해 필수적인 세포 내 질적 조절작용이다. 노화가 진행되는 동안 autopahgy에 의한 degradation 효율성 저하와 그로 인한 세포 내 부산물의 축적이 증가하 여 결국, 근육의 약화를 초래한다. 그러므로 본 연구의 목적은 골격근에서 운동에 의한 autopahgy 관련 단백질의 변화를 규명하는데 있다. 이를 위해 24마리의 Young 그룹과 Old 그룹을 나누어 각각 대조군 $(\mathrm{n}=6)$ 과 운동군 $(\mathrm{n}=6)$ 으로 배정하였다. 운동은 8 주간 주 5 회 실시하였고, 트레드밀 속도 $16.4 \mathrm{~m} / \mathrm{min}$ 와 경사도 $4 \%$ 로 설정하여 40 분간 지속적인 운동을 실시하였다. autopahgy 관련 단백질에 대한 검증 결과 Young 그룹과 비교하여 Old 그룹에서 LC3-1, Beclin-1, Atg7은 모두 유의하게 감소하였다. 그러나 8주간의 규칙적인 운동에 의하여 autophagy 관련 단 백질은 증가하는 것으로 나타났다. 따라서 노화에 의해 약화된 autopahgy 기능은 규칙적인 운동에 의해 개선될 수 있을 것으로 사료된다. 